\title{
THE EFFECTS OF FIRE AND MANUAL BIOMASS REMOVAL ON THE VEGETATION OF GRANITE INSELBERGS
}

\author{
John T. Hunter \\ School of Environmental and Rural Science, University of New England, \\ Elm Avenue, Armidale, New South Wales 2351, Australia \\ Tel.: +61-410442452; e-mail: jhunter8@bigpond.com
}

\section{ABSTRACT}

The vegetation on granite inselbergs (island mountains) within the New England Bioregion of eastern Australia and the adjacent matrix were chosen as subjects in this study on the effects of aboveground biomass removal on community recovery. Undisturbed inselberg vegetation was treated by manual removal of biomass through clipping and also by burning. Inselbergs and the adjacent matrix that had been burned the previous year were also treated to an additional burn. The recovery of vegetation was measured over the following year across all experiments. The change in vegetation composition was analyzed using Detrended Correspondence Analysis (DCA), Generalized Linear Modeling (GLM), and variance partitioning of Canonical Correspondence Analysis (CCA) results, along with SIMPER and PERMANOVA analysis of composition difference and treatment interactions. Species turnover between start and end points of monitoring was also tested for significance between treatments. Comparison of floristic composition before experimentation and at the end point (12 months later) indicated that a single clipping of biomass had little statistical effect on inselberg floristic composition. In contrast, previously unburned inselbergs treated by fire did not recov-

\section{RESUMEN}

La vegetación en islas montañosas graníticas dentro de la bioregión de Nueva Inglaterra en el Este de Australia y la matriz adyacente fueron elegidas como tema en este estudio sobre los efectos de la biomasa sobre el suelo en la recuperación de la comunidad. La vegetación no disturbada en islas montañosas fue tratada mediante la remoción manual de la biomasa mediante su corte y también mediante quemas. Las islas montañosas y la matriz adyacente que habían sido quemadas el año anterior también fueron tratadas con una quema adicional. La recuperación de la vegetación fue medida al año siguiente en todos los experimentos. El cambio en la composición de la vegetación fue analizado utilizando los resultados de análisis de correspondencia (DCA), modelo linear generalizado (GLM), y partición de la varianza del análisis canónico de correspondencia (CCA), junto con los análisis de composición de la diferencia e interacciones de los tratamientos SIMPER y PERMANOVA. El cambio de las especies entre los monitoreos al comienzo y al final fue también probado mediante la significancia entre tratamientos. La comparación en la composición florística antes del experimento y al final del mismo (12 meses después), indicó que una sola corta de biomasa tiene muy poca incidencia en la composición florística de la vegetación de estas islas. En contraste, la vegetación de las islas montañosas tratadas con fuego y que previamente no habían sido quemadas, no recuperaron sus condiciones iniciales. La im- 
er to starting conditions. The imposition of a second burn did not significantly change the composition on inselbergs or within the matrix. Subsequent fires on inselbergs increased species richness within plots. This increase in richness was associated with a loss of the previous endemic obligate seeding dominants and an increase in ubiquitous resprouting taxa, leading to the homogenization of inselberg floras and decreasing their distinctiveness from the matrix. posición de una segunda quema no cambió de forma significativa la composición florística de las islas montañosas o dentro de la matriz. Fuegos subsecuentes incrementaron la riqueza de especies dentro de las parcelas. Este incremento en la riqueza fue asociado con una pérdida de las especies endémicas dominantes que se reproducían obligadamente por semillas y un incremento en los taxa rebrotantes más ubicuos, llevando a una homogeneización de la flora de las islas montañosas y decreciendo su diferenciación de la matriz.

Keywords: Australia, CCA, New England Batholith, rock outcrop, variance partitioning

Citation: Hunter, J.T. 2017. The effects of fire and manual biomass removal on the vegetation of granite inselbergs. Fire Ecology 13(1): 127-137. doi: 10.4996/fireecology.1301127

\section{INTRODUCTION}

Large granite outcrops are often referred to as inselbergs, which is a geological term originating from the German insel (island) and berg (mountain). These features are relictual, remaining above the general landscape while the surrounding areas are lowered through weathering (Twidale 1982). Vegetation on inselbergs is often visually discordant from the adjacent matrix and can have a high degree of taxonomic novelty (McGann 2002). Within eastern Australia, inselbergs in areas of high rainfall ( $>1000 \mathrm{~mm}$ per annum) generally support dense, closed heath within a matrix of open or closed forests (Hunter and Clarke 1998, Hunter 2003b, Hunter and Sheringham 2008). Within the New England Bioregion (NEB) of eastern Australia, 24\% of inselberg species are restricted to and dominate the habitat, with inselbergs in the far northeast sharing almost no species with the adjacent matrix (McGann 2002).

The flora of inselbergs within eastern Australia are highly con-generic with other heaths and shrublands of the region and the encompassing matrix (Clarke 2002a, 2002b; Hunter
$2003 b$, 2004). This has led to the assignment of prescribed fire regimes from structurally similar, but potentially evolutionarily and floristically dissimilar floras (Hunter 2016), to inselberg vegetation (Bradstock et al. 1995, Hunter 1998, Clarke and Fulloon 1999, Keith 2004, Kenny et al. 2004). The island nature of the inselbergs stranded within, but above and separate from, the surrounding matrix imposes physical differences that change the nature, behavior, and effect of fire within the landscape. Vegetation on these inselbergs occur in small pockets surrounded by large expanses of bare rock, islands within islands (Ornduff 1987), reducing the potential for fire to carry into them. Even if one patch burns, often only under conditions of a high intensity matrix fire, there is a high likelihood it will not reach an adjacent patch on the same inselberg. It is therefore not surprising that available evidence suggests inselberg floras may not be fire adapted, unlike other structurally similar heath-like communities in eastern Australia (Ashton and Webb 1977; Fuls et al. 1992; Groger and Barthlett 1996; Hopper et al. 1997; Lawler et al. 1998; Hunter 2003a, 2016). Disturbances such as fire are important in structuring plant 
communities and have the potential to influence the occurrence and density of species within a community (Keith 2004, Croft et al. 2015). Fires, for example, affect vegetation directly and indirectly by killing some organs or plants and stimulating others (Williams and Gill 1995). Anecdotal observations suggest that increasing fire frequency on inselbergs of the NEB to that of other heaths may cause significant floristic change, reducing the number of endemics and obligate seeders in favor of resprouting generalists (Binns 1992, Hunter et al. 1998, Hunter 2016).

Even though a high degree of con-generic taxa are shared between inselbergs and the surrounding matrix, evidence suggests that vegetation on inselbergs within the NEB will not return readily to its original composition after biomass removal. Hunter (2003b) suggested that, in general, inselberg vegetation of the NEB had not evolved to cope with biomass removal of any kind (fire or grazing). It is therefore not clear if recovery from fire and manual biomass removal will illicit the same responses on inselbergs of the NEB. By tracing floristic change over a 12-month period after manual removal of biomass and by fire, I tested the null hypothesis that recovery will be similar. I also tested what effect consecutive fires have on the flora of inselbergs and if this leads to increased divergence from typical undisturbed inselberg floristic composition. These imposed disturbances will test if such perturbations lead to a closer affinity with the matrix that Hunter $(2003 b)$ predicted is naturally prone to higher fire and grazing impacts.

\section{METHODS}

\section{Study Area}

Bald Rock National Park occurs within the NEB of New South Wales, Australia. The study area has the highest proportion of inselberg endemic taxa within the NEB (Hunter 2002). An area of two by two kilometers was chosen, approximately two kilometers south $\left(-28^{\circ} 53^{\prime} \mathrm{S}, 152^{\circ} 00^{\prime} \mathrm{E}\right)$ of Bald Rock itself (the largest granite monolith in the Southern Hemisphere, 400 ha in size). Altitudes ranged from $1100 \mathrm{~m}$ to $1220 \mathrm{~m}$ and mean annual rainfall was $900 \mathrm{~mm}$ to $1000 \mathrm{~mm}$ per annum. The vegetation on inselbergs within the region consists of heathlands and open shrublands, though small, shallow soil basins may be dominated by wet or dry herbfields, depending on season and rainfall (Hunter and Clarke 1998). The adjacent matrix is dominated by open forests dominated by Eucalyptus L'Hér. species, with a prominent understory of shrubs (primarily Fabaceae, Proteaceae, Myrtaceae, and Rutaceae), and grasses and herbs (see Hunter 2004b).

\section{Treatments}

Experimentation occurred between December 1995 and January 1997. Three separate experiments involving burning and clipping were implemented, as follows.

1. On unburned patches within the inselbergs, we installed three treatments of control (unburned and unclipped), manual clipping (removing aboveground biomass at ground level), and burn only.

2. On the vegetation patches within the inselbergs that were burned one year prior to this experiments, we had two treatments of control (burned one year ago) and reburned.

3. On the matrix between the inselbergs that burned one year prior to this experiment, we installed two treatments of control (burned one year ago) and reburned.

As the entire Park and neighboring areas had been burned, no unburned matrix was included in the study. Three locations were chosen for each of the seven treatments (unburned 
and burned inselberg vegetation patches; burned matrix vegetation), and two $2 \mathrm{~m} \times 2 \mathrm{~m}$ plots were randomly placed within each treatment at each location. A combined total of 42 plots were placed.

The corners of each plot were marked by $1.5 \mathrm{~m}$ tall stakes and a $2 \mathrm{~m} \times 2 \mathrm{~m}$ grid of durable cord was created, consisting of 16 squares each measuring $50 \mathrm{~cm} \times 50 \mathrm{~cm}$. This grid was hooked over each of the four corner posts and moved, up or down, depending on the recruiting height of the plants. All aboveground detectable vascular plant taxa were scored for presence within each of the 16 subplots. Data were collected before the applied treatment and again once per month, for a period of 12 months, with the exception of May 1996 (due to extensive rains and flooding), and September and November 1996 (due to fires in the general area). In total, 402 temporal plots were recorded for richness and frequency. Taxon nomenclature follows that of PlantNET (http://plantnet.rbgsyd.nsw.gov.au/; accessed February 2016).

\section{Statistical Analysis}

Initial Detrended Correspondence Analysis (DCA) produced a gradient length of $<3$ and thus the unconstrained unimodal DCA was recommended by the CANOCO package (ter Braak and Šmilauer 2012) as the most appropriate method for analysis of unburned inselberg and reburned inselberg datasets. While non-metric multi-dimensional scaling (NMDS) has been shown to perform as well or better than DCA with fewer underlying assumptions (McCune and Grace 2002), it does not perform as well as DCA when species are heterogeneous in their distributions (Ruokolainen and Salo 2006). Inselberg vegetation within the study region shows a high degree of idiosyncrasy in species occurrences (high pattern diversity; Hunter 2004a), thus DCA was chosen as the more appropriate ordination technique. Canonical Correspondence Analy- sis (CCA; as recommended by the CANOCO advisor module) after forward selection of variables (1000 iterations) and Holm's correction (ter Braak and Šmilauer 2012) was used to analyze the full inselberg dataset (all inselberg treatments combined). Variables incorporated in analysis included location data (UTM easting and northing), time since clearing (in months), time since burn (in months), and number of burns (none, experimental burn 1995 only; wildfire 1994 and experimental burn 1995). A nominal figure of 100 months was given to unaffected plots.

PERMANOVA analysis using Bray-Curtis similarity measure within the PAST $2.17 \mathrm{~b}$ software package (Hammer et al. 2001) was used on the final recording date data (12 months after treatments) for matrix, unburned inselberg, and reburned inselberg datasets to test for the significance of site, treatment and site, and treatment interactions. Permutational MANOVA (PERMANOVA) allows analysis of response data within complex experimental designs by permutations to make it distribution free. To test if significant differences existed in the magnitude of compositional change from the before treatment datasets and final recording datasets across treatments, the turnover between first and last recording was calculated in PAST 2.17b using Whittaker's beta diversity measure. The subsequent beta diversity scores were analyzed across treatments using ANOVA and Tukey's pairwise comparisons within PAST 2.17b. SIMPER analysis using Bray-Curtis similarity measure (PAST 2.17b) was used against all inselberg unburned sites and burned sites to explore which taxa were most responsible for differences between unburned and burned inselberg vegetation. SIMPER compares the contribution of each species to the similarity, thus identifying those species contributing most to the discrimination of predefined groups. The McGann (2002) insularity scores were applied to the taxa along with known fire responses based on field observations (obligate seeding or re- 
sprouting) to further investigate the implications of any floristic change noted.

\section{RESULTS}

In total, 129 vascular plant taxa were recorded within plots during the project. The DCA analysis showed general clustering based on location within both the inselberg and matrix plots (Figures 1 through 3). PERMANOVA (Bray-Curtis Similarity) analysis of the interactions within the experimental design indicates a significant effect of location on the results obtained from both the unburned and reburned inselbergs (experiments 1 and 2) and between treatments on the unburned inselbergs (experiment 1) (Table 1). Only unburned inselbergs showed a significant turnover difference between unburned and unclipped (i.e., control) and treatment (burned or clipped) sites based on pretreatment and 12-months-after-treatment survey periods (Table 2). Reburned inselbergs showed the least change between initial and final surveys. There was no significant difference between control and clearing turnover on

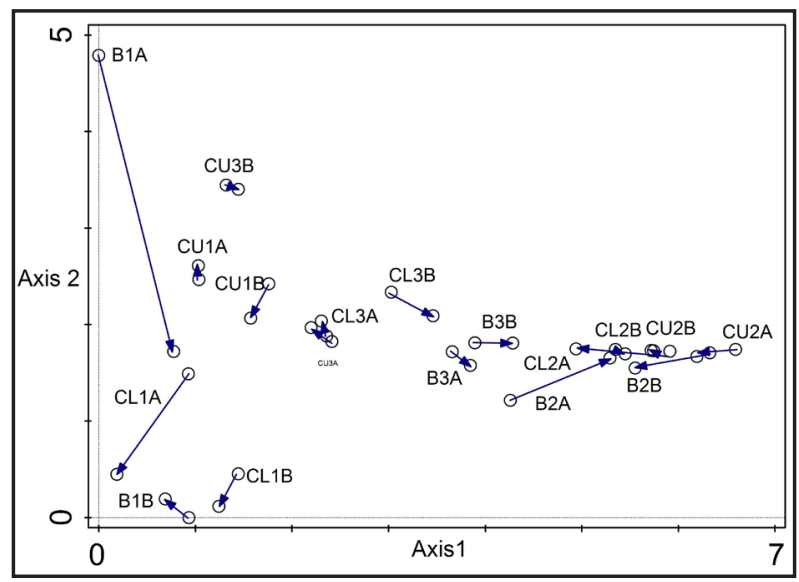

Figure 1. DCA time series before treatment to final recording (direction of arrow) on previously unburned inselbergs. The distance between plots relates to compositional difference (floristics and frequency; experiment 1). Treatments $C U=$ unburned or clipped, $\mathrm{CL}=$ clipped only, $\mathrm{B}=$ burned. 1 through 3 = inselbergs; $\mathrm{A}$ and $\mathrm{B}=$ replicates.

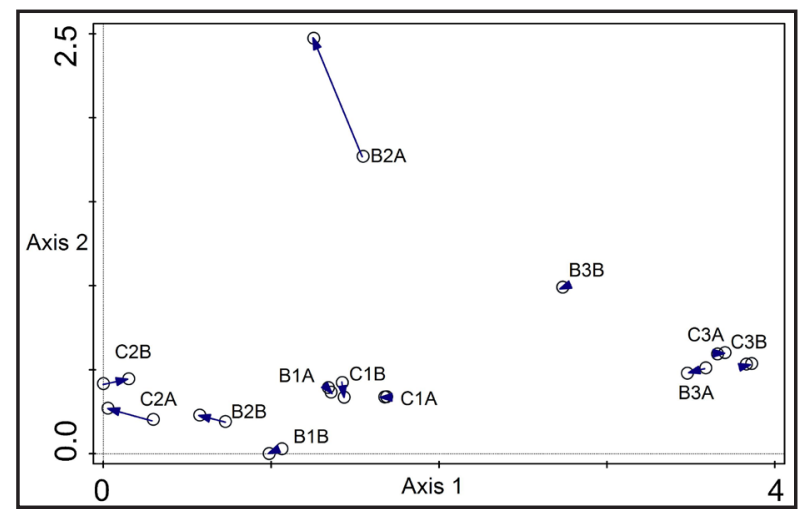

Figure 2. DCA time series before treatment to final recording (direction of arrow) on previously burned (12 months prior) inselbergs (experiment 2). The distance between plots relates to compositional difference (floristics and frequency). Treatments $\mathrm{C}=$ burned once, $\mathrm{B}=$ reburned (twice burned ). 1 through 3 = inselbergs; A and B = replicates.

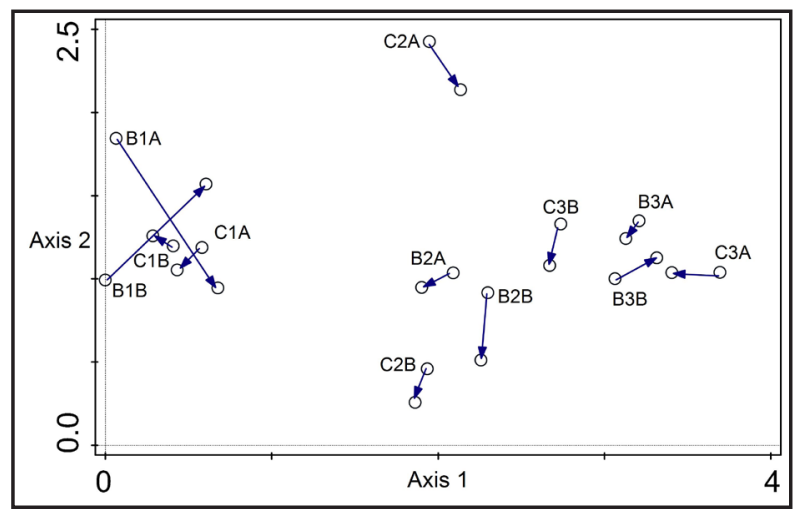

Figure 3. DCA time series before treatment to final recording (direction of arrow) on previously burned matrix vegetation (floristics and frequency; experiment 3). The distance between plots relates to compositional difference. Treatments $\mathrm{C}=$ burned once, $\mathrm{B}=$ reburned (twice burned). 1 through $3=$ matrices; $\mathrm{A}$ and $\mathrm{B}=$ replicates.

unburned inselbergs, but there was a significant difference in turnover between burning and clipping treatments (Table 2).

The CCA of all inselberg floristic datasets explained a total of $15.8 \%$ of adjusted variation and indicates that species density (richness per plot) increases with time since fire and time since clearing (Figure 4). Location (eastness and northness) was found to be of 
Table 1. Significant treatment interactions in floristic turnover based on $P$ values of Whittaker's Beta Diversity before and 12 months after treatment. Asterisks indicate significant interactions at the 0.05 level.

\begin{tabular}{lcc}
\hline Treatment interactions & Unburned & Reburned \\
\hline Location & $0.0001^{*}$ & $0.0001^{*}$ \\
$\begin{array}{l}\text { Treatment } \\
\text { (burned or cleared) }\end{array}$ & 0.0537 & 0.3010 \\
Location and treatment & $0.0145^{*}$ & 0.2516 \\
\hline
\end{tabular}

Table 2. Significant treatment interactions in floristic turnover based on $P$ values of Whittaker's Beta Diversity before and 12 months after treatment. Asterisk indicates significant interactions at the 0.05 level.

\begin{tabular}{lccc}
\hline $\begin{array}{l}\text { Treatment } \\
\text { interactions }\end{array}$ & Unburned & Reburned & Matrix \\
\hline $\begin{array}{l}\text { Control and } \\
\text { clearing }\end{array}$ & 0.2034 & NA & NA \\
$\begin{array}{l}\text { Burning and } \\
\text { clearing }\end{array}$ & $0.0464^{*}$ & NA & NA \\
$\begin{array}{l}\text { Control and } \\
\text { burning }\end{array}$ & $0.0187^{*}$ & 0.8017 & 0.5960 \\
\hline
\end{tabular}

significance in terms of composition but has less influence on species density than the other variables tested. Increasing fire frequency is associated with the greatest positive change in species density. However, this change in density is associated with a significant change in composition. Based on SIMPER analysis, burned inselberg sites are associated with a change in dominance from outcrop endemic, largely obligate seeders, to more generalist species that are more commonly resprouters (Table 3). Based on variance partitioning of the CCA results, the effects of location (spatial) had the most significant unique effect on compositional change, followed by burning (fire) and then clipping (Figure 5).

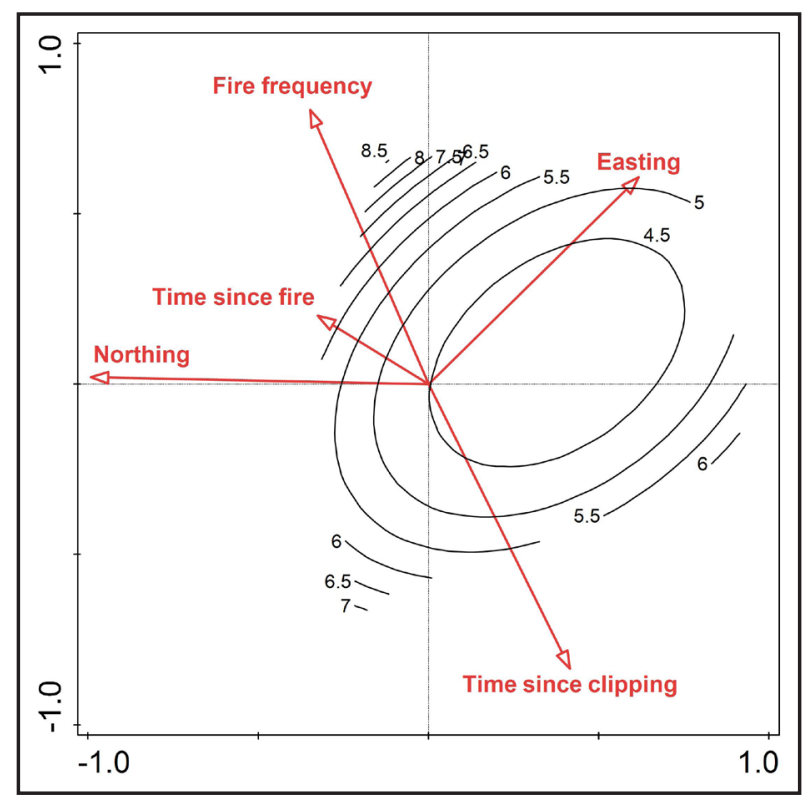

Figure 4. Isolines of species richness change within treatments (unburned, burned, reburned, and clipping) on inselbergs based on quadratic generalized linear model (GLM) along with projected significant environmental variables $(<0.05)$ based on forward selection and Holm's correction. Vector length indicates the strength of influence on the ordination.

\section{DISCUSSION}

The results indicate that burning caused a greater compositional change than clipping or unburned treatments on undisturbed inselbergs (experiment 1). Furthermore, burning and, in particular, frequent burning caused a significant change in the life history characteristics of the component inselberg flora, favoring resprouting habitat generalists at the expense of obligate-seeding rare endemics. Removal of biomass by clipping as a single event made no appreciable difference to the species composition. Thus, how biomass is removed is a significant factor in relation to inselberg vegetation recovery, with fire being more disruptive than clipping (and thus possibly grazing).

In contrast, species composition on inselbergs and the matrix that had been burned the previous year and reburned (experiments 2 and 
Table 3. SIMPER analysis of flora species contributing to the first $90 \%$ of compositional difference between unburned and burned inselberg vegetation. Species are scored on fire response and the insular guild (insular guild is a measure of species restrictedness to the insular inselberg environment; McGann 2002). Guild $6=$ taxa restricted to granitic inselbergs throughout their distribution; guild $5=$ taxa restricted to granitic and other rock type inselbergs and outcrops; guild $4=$ taxa restricted to inselbergs within the New England Batholith of eastern Australia but other habitats elsewhere; guild $3=$ taxa common on inselbergs but also found in low abundance in matrix vegetation; guild 2 =ubiquitous taxa equally common within inselbergs and matrix floras; guild $1=$ taxa abundant in matrix vegetation but rarely found on inselbergs. $\mathrm{T}=$ tree; $\mathrm{S}=$ shrub; $\mathrm{H}=$ herb; $\mathrm{G}=$ grass.

\begin{tabular}{|c|c|c|c|c|c|}
\hline Unburned & $\begin{array}{l}\text { Insularity } \\
\text { guild }\end{array}$ & $\begin{array}{c}\text { Fire } \\
\text { response }\end{array}$ & Burned & $\begin{array}{l}\text { Insularity } \\
\text { guild }\end{array}$ & $\begin{array}{c}\text { Fire } \\
\text { response }\end{array}$ \\
\hline $\begin{array}{l}\text { Kunzea bracteolata Maiden \& } \\
\text { Betche (S) }\end{array}$ & 6 & $\begin{array}{l}\text { Obligate } \\
\text { seeder }\end{array}$ & Pelargonium australe Willd. (H) & 2 & Resprouter \\
\hline $\begin{array}{l}\text { Leionema ambiens (F.Muell.) Paul } \\
\text { G.Wilson (S) }\end{array}$ & 6 & $\begin{array}{l}\text { Obligate } \\
\text { seeder }\end{array}$ & Ozothamnus obcordatus DC.(S) & 3 & Resprouter \\
\hline $\begin{array}{l}\text { Trachymene sp. aff. incisa Rudge } \\
\text { (H) }\end{array}$ & 6 & Resprouter & $\begin{array}{l}\text { Lomandra multiflora (R.Br.) } \\
\text { Britten }(\mathrm{H})\end{array}$ & 2 & Resprouter \\
\hline $\begin{array}{l}\text { Leptospermum polygalifolium ssp. } \\
\text { montanum Joy Thomps. (S) }\end{array}$ & 3 & Resprouter & Stylidium laricifolium Rich. $(\mathrm{H})$ & 4 & $\begin{array}{l}\text { Obligate } \\
\text { seeder }\end{array}$ \\
\hline $\begin{array}{l}\text { Lomandra filiformis (Thunb.) } \\
\text { Britten (H) }\end{array}$ & 2 & Resprouter & $\begin{array}{l}\text { Petrophile canescens A.Cunn. } \\
\text { ex R.Br. (S) }\end{array}$ & 2 & Resprouter \\
\hline $\begin{array}{l}\text { Schoenus apogon Roem. \& Schult. } \\
\text { (H) }\end{array}$ & 4 & $\begin{array}{l}\text { Obligate } \\
\text { seeder }\end{array}$ & $\begin{array}{l}\text { Rytidosperma monticola } \\
\text { (Vickery) Connor \& Edgar (G) }\end{array}$ & 3 & Resprouter \\
\hline Callitris monticola J.Garden (S) & 6 & $\begin{array}{l}\text { Obligate } \\
\text { seeder }\end{array}$ & $\begin{array}{l}\text { Rytidosperma racemosum } \\
\text { (R.Br.) Connor \& Edgar (G) }\end{array}$ & 2 & Resprouter \\
\hline $\begin{array}{l}\text { Philotheca epilosa (Paul G.Wilson) } \\
\text { P.I.Forst. (S) }\end{array}$ & 6 & $\begin{array}{l}\text { Obligate } \\
\text { seeder }\end{array}$ & $\begin{array}{l}\text { Amperea xiphoclada (Spreng.) } \\
\text { Druce }(\mathrm{H})\end{array}$ & 2 & Resprouter \\
\hline $\begin{array}{l}\text { Gonocarpus micranthus Thunb. } \\
\text { (H) }\end{array}$ & 2 & $\begin{array}{l}\text { Obligate } \\
\text { seeder }\end{array}$ & $\begin{array}{l}\text { Lepidosperma gunnii Boeckeler } \\
(\mathrm{H})\end{array}$ & 4 & Resprouter \\
\hline $\begin{array}{l}\text { Mirbelia speciosa Sieber ex DC. } \\
\text { (S) }\end{array}$ & 3 & $\begin{array}{l}\text { Obligate } \\
\text { seeder }\end{array}$ & $\begin{array}{l}\text { Pomax umbellata (Gaertn.) Sol. } \\
\text { ex A.Rich. }(\mathrm{H})\end{array}$ & 2 & $\begin{array}{l}\text { Obligate } \\
\text { seeder }\end{array}$ \\
\hline $\begin{array}{l}\text { Leucopogon melaleucoides } \\
\text { A.Cunn. ex. DC. (S) }\end{array}$ & 2 & Resprouter & Brachyscome stuartii Benth.(H) & 6 & Resprouter \\
\hline $\begin{array}{l}\text { Leptospermum novae-angliae Joy } \\
\text { Thomps. (S) }\end{array}$ & 6 & $\begin{array}{l}\text { Obligate } \\
\text { seeder }\end{array}$ & Patersonia glabrata R.Br. (H) & 2 & Resprouter \\
\hline Acacia latisepala Pedley (S) & 6 & $\begin{array}{l}\text { Obligate } \\
\text { seeder }\end{array}$ & $\begin{array}{l}\text { Boronia anemonifolia A.Cunn. } \\
\text { (S) }\end{array}$ & 3 & $\begin{array}{l}\text { Obligate } \\
\text { seeder }\end{array}$ \\
\hline Pimelea strigosa Gand. (S) & 3 & Resprouter & $\begin{array}{l}\text { Haemadorum planifolium R.Br. } \\
(\mathrm{H})\end{array}$ & 1 & Resprouter \\
\hline Prostanthera petraea B.J.Conn (S) & 6 & $\begin{array}{l}\text { Obligate } \\
\text { seeder }\end{array}$ & $\begin{array}{l}\text { Platysace ericoides (Sieberi ex } \\
\text { Spreng.) C.Norman (H) }\end{array}$ & 2 & Resprouter \\
\hline $\begin{array}{l}\text { Leucopogon neoanglicus F.Muell. } \\
\text { ex Benth. (S) }\end{array}$ & 6 & $\begin{array}{l}\text { Obligate } \\
\text { seeder }\end{array}$ & $\begin{array}{l}\text { Allocasuarina littoralis (Salisb.) } \\
\text { L.A.S.Johnson (T) }\end{array}$ & 2 & Resprouter \\
\hline
\end{tabular}

3) did not change significantly compared to the unburned plots. This is likely due to the prominence of resprouting species and lack of obligate seeders within the matrix (Hunter $2003 b$ ). Resprouting species are better able to cope with regular disturbances such as frequent fire. Anecdotal observations of frequent fire on inselbergs (in the same region) caused heaths that were dominated by outcrop endemic taxa to be reduced to grasslands and herbfields dominated by ubiquitous resprouting species shared with the matrix such as Lomandra longifolia Labill. and Imperata cylindrica (L.) P.Beauv. (Binns 1992, Hunter et al. 1999). The composition of the vegetation on inselbergs changed from being dominated by 


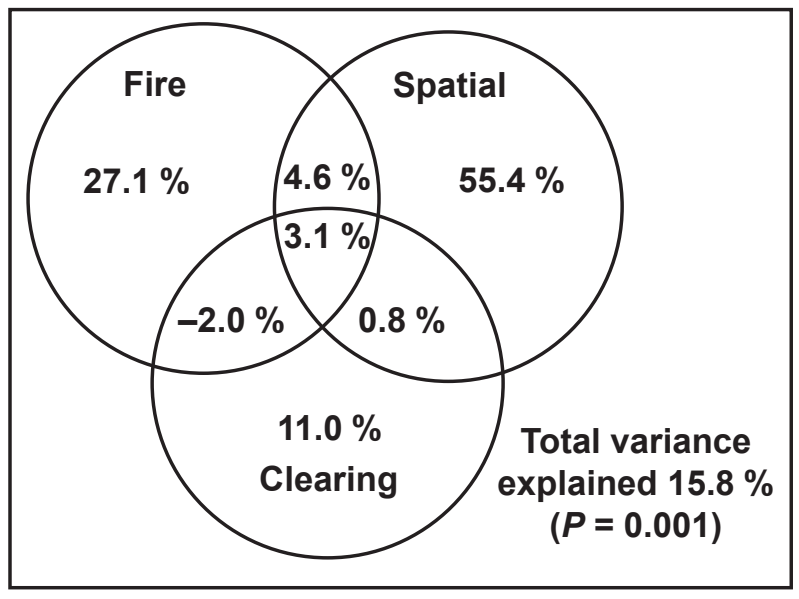

Figure 5. Venn diagram of variance partitioning of full vascular floristic inselberg dataset and significant environmental variables. Values are percentages of the total variation explained by the full model.

endemic obligate seeders to more ubiquitous resprouter taxa that commonly occur within the surrounding matrix within the results presented here, supporting these anecdotal observations. Thus, successive fires cause inselberg floras to be less distinctive and less insular from the surrounding matrix. Inselberg floras are often reported as refuge areas for species unadapted to fire, and these findings support this concept (Heinze et al. 1997; Lawler et al. 1998; Hopper 2000; Hunter 2003b, 2016).

Species richness per plot (density) is often used as a surrogate for understanding the potential benefits of fire to the biodiversity of a community (Russell and Parsons 1978, Clarke 1988, Ross et al. 2002, Etherington and Shapcott 2014). The results presented here would suggest caution in using richness per plot as a sole surrogate or reason to implement strategic fire on inselbergs. Increasing fire frequency was associated with an elevated species richness per plot but not necessarily the rare and endemic taxa. The increase in richness per plot on inselbergs after fire was associated with a loss of the previously dominant, largely rare, endemic taxa being replaced by more common and generalist species. This response would likely homogenize the flora of these otherwise stochastic and highly endemic floras, increasing richness at the site scale but decreasing the richness within the landscape; similar results have been found in other systems (Schultz et al. 2014). Thus, recovery of a frequently burned inselberg within the study area may include a reduction in species richness per plot, but an increase in specialist taxa, increasing landscape diversity.

The effect of location was a major influence across all analyses in structuring the responses of vegetation on inselbergs to the imposed manipulative experimentation. This is irrespective of the locations being within very close proximity to each other (often less than $200 \mathrm{~m}$ ). Inselbergs from the region and elsewhere have a high degree of stochasticity in species occurrence. The harsh conditions, elevated endemicity, local dispersal, and naturally highly fragmented habitat means that there is large spatial and temporal variation in composition (beta and pattern diversity) between adjacent inselbergs or even on the same inselberg within different patches (Hunter 2000, 2003a, 2003b, 2004a; McGann 2002). Thus, what species will occur on an inselberg site is highly idiosyncratic. Furthermore, the composition after a single disturbance event may depend on initial floristic composition more so than other systems. Predicting specific trajectories of community recovery may be more problematic in these systems. The outcomes of strategic burns may be unclear unless detailed knowledge of the original composition of individual vegetation patches is known.

The results presented here are limited by the small scale of the experiments and the short-term nature of monitoring. Due caution should be taken in interpretation of the results. However, the unique nature of the inselberg environment would suggest that even these short-term results will have a long-lasting effect. Granitic inselbergs within the study area share the characteristics of very old, climatically buffered, infertile landscapes (Ocbils; 
Hopper et al. 2016). Due to the harsh environment, limited space and soil, infrequent biomass removing disturbances, and an archipelago-like habitat with limited chances of successful dispersal, taxa on these inselbergs have developed life history characteristics different from those of the matrix (Hunter 2003b, 2016). Endemic species on granitic inselbergs within the study area have been shown to share many of the characteristics typical of Ocbil (Hopper et al. 2016) endemics, such as preservation of the self at the expense of reproduction and dispersal (Hunter 2016). As there are limited spatial resources on inselbergs (small soil islands), the chances to recruit are limited. Therefore, these species share functional traits that place plant resources to persistence in situ rather than reproduction and dispersal (Hunter 2016). A disturbance such as repeated fire that kills these endemic taxa and promotes ubiquitous taxa will have a long-lasting effect on the system. Thus, it is argued that, due to the nature of the inselberg environment and the functional traits of the species therein, the changeover from obligate seeding endemics to resprouting ubiquitous generalists over the experimental period is of relevance, with the changes likely to persist over the long-term.

\section{CONCLUSION}

In terms of landscape fire management, these results highlight the necessity to explore the traits and dynamics of communities based on species' life history traits rather than on the communities' structural characteristics. Equating similar structural types to each other in terms of fire management can lead to inappropriate assignment of guidelines. Currently, suggested implemented fire regimes for inselberg heaths within the study area are the same as those for any heathland landscape regardless of their origin (e.g., coastal heaths, highland heathland swamps). Managers may implement fires as regularly as every seven years with a maximum non-fire period of 30 years (Bradstock et al. 1995, Kenny et al. 2004). Such a regime would likely lead to the extirpation of much of the rare endemic flora within these heaths and the homogenization of the landscape. Based on the life history and functional traits of the endemic flora of these inselbergs, fire is unlikely to have been a regular component of these patches even though they are embedded in a matrix with a relatively frequent fire occurrence (Hunter 2003b, 2016). Inselbergs can form small isolated refuges from fire that exist within a naturally regularly burned landscape. Efforts should not be undertaken to implement managed fires for biodiversity even if they increase richness at the plot scale within these specialized environments.

\section{ACKNOWLEDGEMENTS}

Thanks to the directors of the New South Wales National Parks and Wildlife Services for permission to survey and conduct research within lands manage by them. Thanks also to E. Fallavollita for assistance with research fires at Bald Rock. Thank you to the reviewers and the handling and managing editors for assisting in improving the manuscript.

\section{LITERATURE CITED}

Aston, D.H., and R.N. Webb. 1977. The ecology of granite outcrops at Wilson's Promontory, Victoria. Australian Journal of Ecology 2: 269-296. doi: 10.1111/j.1442-9993.1977. tb01145.x 
Binns, D.L. 1992. Flora survey, Glen Innes Management Area, Northern Region, New South Wales. Forest Resources Series No. 23, Forestry Commission of New South Wales, Sydney, Australia.

Bradstock, R.A., Keith, D.A., and T.D. Auld. 1995. Fire and conservation imperatives and constraints on managing for biodiversity. Pages 323-333 in: R.A. Bradstock, T.D. Auld, D.A. Keith, R.T. Kingsford, D. Lunney, and D.P. Sivertsen, editors. Conserving biodiversity threats and solutions. Surrey Beatty and Sons, Chipping Norton, New South Wales, Australia.

Clarke, P.J. 2002a. Habitat insularity and fire response traits: evidence from a sclerophyll archipelago. Oecologia 132: 582-591. doi: 10.1007/s00442-002-0962-0

Clarke, P.J. 2002b. Habitat islands in fire-prone vegetation: do landscape features influence community composition. Journal of Biogeography 29: 677-684. doi: 10.1046/j.1365-2699. 2002.00716.x

Clarke, P.J., and L. Fulloon. 1999. Fire and rare plants: Torrington State Recreation Area. University of New England, Botany Department, Armidale, New South Wales, Australia.

Clarke, S.S. 1988. Effects of hazard-reduction burning on populations of understory plant species on Hawkesbury sandstone. Australian Journal of Ecology 13: 473-484. doi: 10.1111/j.1442-9993.1988.tb00996.x

Croft, P.J., Hunter, J.T., N. Reid. 2015. Forgotten fauna: habitat attributes of long-unburnt open forests and woodlands dictate a rethink of fire management theory and practice. Forest Ecology and Management 366: 166-174. doi: 10.1016/j.foreco.2016.02.015

Etherington, R., and A. Shapcott. 2014. Do habitat fragmentation and fire influence variation in plant species composition, structure and diversity within three regional ecosystems on the Sunshine Coast, Queensland, Australia? Australian Journal of Botany 62: 38-47. doi: 10.1071/BT13232

Fuls, E.R., G.J. Bredenkamp, and N. van Rooyen. 1992. Plant communities of the rocky outcrops of the northern Orange Free State, South Africa. Vegetatio 103: 79-92.

Gröger, A., and W. Barthlott. 1996. Biogeography and diversity of the inselberg (Laja) vegetation of southern Venezuela. Biodiversity Letters 3: 165-179. doi: 10.2307/2999674

Hammer, O., D.A.T. Harper, and P.D. Ryan. 2001. PAST: Paleontological Statistics software package for education and data analysis. Palaeontologia Electronica 4: 9.

Heinze, D., G. O’Neill, E. Briggs, and T. Cardwell. 1998. Buffalo Sallow Wattle Acacia phlebophylla of Mount Buffalo. Victorian Naturalist 115: 205-209.

Hopper, S.D. 2000. Floristics and Australian granitoid inselberg vegetation. Pages 391-408 in: S. Porembski and W. Barhtlott, editors. Inselbergs: biotic diversity of isolated rock outcrops in tropical and temperate regions. Springer, Berlin, Germany. doi: 10.1007/978-3-64259773-2 18

Hopper, S.D., A.P. Brown, and N.G. Marchant. 1997. Plants of western Australian granite outcrops. Journal of the Royal Society of Western Australia 80: 141-158.

Hopper, S.D., F.A.O. Silveira, and P.L. Fiedler. 2016. Biodiversity hotspots and Ocbil theory. Plant Soil 403: 167-216. doi: 10.1007/s11104-015-2764-2

Hunter, J.T. 1988. Granite outcrop vegetation of Wilson's Promontory. Victorian Naturalist 115: $322-325$.

Hunter, J.T. 2003a. Factors affecting range size differences for plant species on rock outcrops in eastern Australia. Diversity and Distributions 9: 211-220. doi: 10.1046/j.1466-822X. 2003.00167.x

Hunter, J.T. 2003b. Persistence on inselbergs: the role of obligate seeders and resprouters. Journal of Biogeography 30: 497-510. doi: 10.1046/j.1365-2699.2003.00876.x 
Hunter, J.T. 2004a. Factors affecting the nestedness of rock outcrop floras of the New England Batholith of eastern Australia. Proceedings of the Royal Society of Queensland 111: 31-38.

Hunter, J.T. 2004b. Vegetation of Basket Swamp National Park, Northern Tablelands, New South Wales. Cunninghamia 8: 453-466.

Hunter, J.T. 2016. Differences in functional trait distribution between inselberg and adjacent matrix floras. International Journal of Ecology (2016): article ID 6417913. doi: $10.1155 / 2016 / 6417913$

Hunter, J.T., and P.J. Clarke. 1998. The vegetation of granitic outcrop communities on the New England Batholith of eastern Australia. Cunninghamia 5: 547-618.

Hunter, J.T., and P.S. Sheringham. 2008. Vegetation and floristic diversity in Gibraltar Range and part of Washpool National Parks, New South Wales. Cunninghamia 10: 439-474.

Hunter, J.T., E. Fallavollita, and V.H. Hunter. 1998. Observations on the ecology of Muehlenbeckia costata M.S. (Polygonaceae), a rare fire-ephemeral species occurring on the New England Batholith of northern New South Wales and southern Queensland. Victorian Naturalist 115: 9-17.

Keith, D.A. 2004. Ocean shores to desert dunes: the native vegetation of New South Wales and the ACT. Department of Environment and Conservation, Sydney, Australia.

Kenny, B., E. Sutherland, E. Tasker, and R. Brastock. 2004. Guidelines for ecologically sustainable fire management: NSW biodiversity strategy July 2004. Bushfire Research Unit, Biodiversity Research and Management Division, New South Wales National Parks and Wildlife Service, Sydney, Australia.

Lawler, S., S. Brown, G. Edney, S. Howlett, and P. Love. 1998. Buffalo Sallee at the Back Wall: an alpine species adapted to fire and drought. Victorian Naturalist 115: 201-2015.

McGann, T.D. ${ }^{1}$ 2002. How insular are ecological "islands"? An example from the granitic outcrops of the New England Batholith of Australia. Proceedings of the Royal Society of Queensland 110: 1-13.

McCune, B., and J.B. Grace. 2002. Analysis of ecological communities. MjM Software Design, Gleneden Beach, Oregon, USA.

Ornduff, R. 1987. Islands within islands: plant life on granite outcrops of Western Australia. University of Hawaii Press, Honolulu, USA.

Ross, K.A., B.J. Fox, and M.D. Fox. 2002. Changes to plant species richness in forest fragments: fragment age, disturbance and fire history may be as important as area. Journal of Biogeography 29: 749-765. doi: 10.1046/j.1365-2699.2002.00722.x

Ruokolainen, L., and K. Salo. 2006. Differences in performance of four ordination methods on a complex vegetation dataset. Annals Botanici Fennici 43: 269-275.

Schultz, N.L., N. Reid, G. Lodge, and J.T. Hunter. 2014. Broad-scale patterns in plant diversity vary between land uses in a variegated temperate Australian agricultural landscape. Austral Ecology 39: 855-863. doi: 10.1111/aec.12154

ter Braak, C.J.F., and P. Šmilauer. 2012. CANOCO reference manual and users guide software for ordination (version 5.0). Microcomputer Power, Ithaca, New York, USA.

Twidale, C.R. 1982. Granite landforms. Elsevier, Amsterdam, The Netherlands.

Williams, J.E., and A.M. Gill. 1995. The impact of fire regimes on native forests in eastern New South Wales. Environmental Heritage Monograph Series No. 2. National Parks and Wildlife Service of New South Wales, Sydney, Australia.

\footnotetext{
${ }^{1}$ T.D. McGann and J.T. Hunter are synonymous authors.
} 